\title{
Observation Composed of a Parameter and Chance Error: An Analytical Method of Determining the Parameter
}

\author{
Dhritikesh Chakrabarty \\ Department of Statistics, Handique Girls' College, Guwahati-781001, Assam, India. \\ e-mail:dhritikesh.c@rediffmail.com,dhritikeshchakrabarty@gmail.com
}

\begin{abstract}
An analytical method has been developed to determine the true value of a parameter from its observations in the situation where the observations include chance errors but not any assignable error. The method was applied to find out the natural annual maximum and the natural annual minimum of ambient air temperature observed at Guwahati and the reliability of the method has been discussed.
\end{abstract}

Key Words: Parameter, chance error, observation, determination of parameter, analytical method.

\section{Introduction}

There are many situations where observations

$$
X_{1}, X_{2}, \ldots \ldots \ldots, \quad X_{n}
$$

are composed of some parameter and chance errors i.e.

$$
X_{i}=\mu+\varepsilon_{i}, \quad(i=1,2, \ldots \ldots \ldots, n)
$$

where (i) $\mu$ is the parameter

and (ii) $\varepsilon_{i}$ is the chance error associated with $X_{i}$.

The existing methods of estimation, namely least squares method, maximum likelihood method, minimum variance unbiased method, method of moment and method of minimum chi-square provide

$$
\bar{X}=\frac{1}{n}\left(\sum_{i=1}^{n} X_{i}\right)
$$

as estimator of the parameter $\mu$. This estimator suffers from an error

$$
\overline{\varepsilon_{i}}=\frac{1}{n}\left(\bar{\Sigma}_{i=1}^{n} \varepsilon_{i}\right)
$$

which may not be zero [Allan (1962), Barnard (1949), Hald (1999), Ivory (1825), John (2000), Le Cam (1990), Kendall \& Stuart (1977), Lehman \& Casella (1998, Walker \& Lev (1965)]. In other 
words, none of these methods can provide the true value of the parameter $\mu$. In order to meet up this crisis, an analytical method has been developed for determining the true value of the parameter $\mu$ in such a situation. This paper is based on the development of this method and on one numerical application of the method in determining the annual maximum and the annual minimum of ambient air temperature at Guwahati.

The method developed is based on the theory of normal probability distribution discovered by a German mathematician Carl Friedrich Gauss, the credit for which discovery is also given by some authors to a French mathematician Abraham De Moivre who established that the normal distribution is an approximation to the binomial distribution discovered by James Bernoulli [Bernoulli (1713), Brye (1995), Chakrabarty (2005 , 2008)), De Moivre (1711 , 1718), Hazewinkel (2001), Marsagilla (2004), Stigler (1982), Walker (1985)]. This distribution is described by the probability density function

$$
\begin{aligned}
f(x: \mu, \sigma)= & \left\{\sigma(2 \pi) \frac{1}{2}\right\}^{-1} \exp \left[-1 / 2\{(x-\mu) / \sigma\}^{2}\right], \\
& -\infty<x<\infty,-\infty<\mu<\infty, 0<\sigma<\infty .
\end{aligned}
$$

where (i) $X$ is the associated normal variable,

(ii) $\mu$ and $\sigma$ are the two parameters of the distribution

and (iii) Mean of $X=\mu \&$ Standard Deviation of $X=\sigma$.

The distribution is symmetric and satisfies the following properties:

If $X \sim N(\mu, \sigma)$, then

$$
\begin{gathered}
\text { (i) } P(\mu-1.96 \sigma<X<\mu-1.96 \sigma)=0.95 \text {, } \\
\text { (ii) } P(\mu-2.58 \sigma<X<\mu-2.58 \sigma)=0.99 \\
\text { \& (iii) } P(\mu-3 \sigma<X<\mu-3 \sigma)=0.9973 .
\end{gathered}
$$

\section{Development of the Method}

In the situation under consideration, the observations

$$
X_{1}, X_{2}, \ldots \ldots \ldots, X_{n}
$$

are such that they satisfy

$$
X_{i}=\mu+\varepsilon_{i}, \quad(i=1,2, \ldots \ldots \ldots, n)
$$

were $\varepsilon_{1}, \varepsilon_{2}, \ldots \ldots \ldots, \varepsilon_{n}$ are values of the chance error $\varepsilon$ associated with $X_{1}, X_{2}, \ldots \ldots \ldots \ldots, X_{n}$ respectively.

It is to be noted that

(1) $X_{1}, X_{2}, \ldots \ldots \ldots \ldots, X_{n}$ are known,

(2) $\mu, \varepsilon_{1}, \varepsilon_{2}, \ldots \ldots \ldots \ldots, \varepsilon_{n}$ are unknown 
and (3) the number of linear equations in (2.1) is $n$ with $(n+1)$ unknowns implying that the equations are not solvable mathematically.

\section{Reasonable facts /Assumptions regarding $\varepsilon_{i}$ :}

(1) $\varepsilon_{1}, \varepsilon_{2}, \ldots \ldots \ldots, \varepsilon_{n}$ are unknown values of the variable $\varepsilon$.

(2) The values of the chance errors $\varepsilon_{1}, \varepsilon_{2}, \ldots \ldots \ldots \ldots, \varepsilon_{n}$ are very small relative to the corresponding values of the variable $\mathrm{X}_{\mathrm{i}}$ ie. $X_{1}, X_{2}, \ldots \ldots \ldots, X_{n}$.

(3) The variable $\varepsilon_{i}$ assumes both positive and negative values.

(4) $P(-a-d a<\varepsilon<-a)=P(a<\varepsilon<a+d a)$ for every real $a$.

(5) $P(a<\varepsilon<a+d a)>P(b<\varepsilon<b+d b)$ $\& P(-a-d a<\varepsilon<-a)<P(-b-d b<\varepsilon<-b)$ for every real positive $a<b$.

(6) The facts (3), (4) \& (5) together imply that $\varepsilon$ obeys the normal probability law.

(7) Sum of all possible values of each $\varepsilon$ is 0 (zero) which together with the fact (6) implies that $E(\varepsilon)=0$.

(8) Standard deviation of $\varepsilon$ is unknown and small, say $\sigma_{\varepsilon}$.

(9) The facts (6), (7) \& (8) together imply that $\varepsilon$ obeys the normal probability law with mean (expectation) 0 and standard deviation $\sigma_{\varepsilon}$. Thus

$$
\varepsilon \sim N\left(0, \sigma_{\varepsilon}\right)
$$

Note (2.1): Since $\boldsymbol{\varepsilon}_{1}, \varepsilon_{2}, \ldots \ldots \ldots, \varepsilon_{n}$ are independently and identically distributed $N\left(0, \sigma_{\varepsilon}\right)$ variates, their mean defined by

$$
\bar{s}_{i}=\frac{1}{n}\left(\sum_{i=1}^{n} \varepsilon_{i}\right)
$$

is a $N\left(0, \sigma_{\varepsilon} / \sqrt{ } n\right)$ variable.

\subsection{The Method}

Let the observations be arranged in ascending order of magnitude as -

$$
X_{(1)}<X_{(2)}<\ldots \ldots \ldots .<X_{(n)}
$$

From the model (2.1) satisfied by the observations,

$$
X_{(i)}=\mu+\varepsilon_{(i)} \quad, \quad(i=1,2, \ldots \ldots \ldots, n)
$$

where $\varepsilon_{(1)}<\varepsilon_{(2)}<\ldots \ldots \ldots \ldots<\varepsilon_{(n)}$

which implies that $X_{(1)}$ contains the maximum negative error and $X_{(n)}$ contains the maximum positive error among the errors accompanied with the observations. 
Now, let us construct the $n$ averages defined by

$$
\bar{X}_{(0)}(1)=\frac{1}{n-1} \sum_{j=1, j=i}^{n} X_{(0)}, \quad(i=1,2, \ldots \ldots \ldots, n)
$$

Here, $\quad \bar{X}_{(1)}(1)>\bar{X}_{(2)}(1)>\ldots \ldots \ldots \ldots \ldots . \bar{X}_{(n-1)}(1)>\bar{X}_{(n)}(1)$

From the model (2.1),

$$
\bar{X}_{(i)}(1)=\mu+\bar{s}_{i}(1)
$$

where

$$
\bar{\varepsilon}_{(i)}(1)=\frac{1}{n-1} \sum_{j=1, j=i}^{n} \varepsilon_{(j)}, \quad(i=1,2, \ldots \ldots \ldots, n)
$$

By Note (2.1), some of the averages $\bar{\varepsilon}_{(1)}(1), \bar{\varepsilon}_{(2)}(1), \ldots \ldots \ldots \ldots, \bar{s}_{(n-1)}(1), \bar{s}_{(n)}(1)$ will lie above 0 and the others below 0. Consequently, some of the averages

$\bar{X}_{(1)}(1), \bar{X}_{(2)}(1), \ldots \ldots \ldots \ldots, \bar{X}_{(n-1)}(1), \bar{X}_{(n)}(1)$

will lie above $\mu$ and the others below $\mu$.

Suppose, $\quad \bar{X}_{(1)}(1), \bar{X}_{(2)}(1), \ldots \ldots \ldots, \bar{X}_{(k)}(1) \quad$ fall above $\mu$ and $\quad \bar{X}_{(k+1)}(1), \bar{X}_{(k+2)}(1), \ldots \ldots \ldots, \bar{X}_{(n)}(1)$ fall below $\mu$.

Then $\mu$ will lie within $\quad \bar{X}_{(k+1)}(1) \& \bar{X}_{(k)}(1)$ with

$$
\bar{X}_{(k+1)}(1)<\mu<\bar{X}_{(k)}(1)
$$

Of course, it is trivial that

$$
\bar{X}_{(n)}(1)<\mu<\bar{X}_{(1)}(1)
$$

The inequality (2.9) can help to determine the true value of $\mu$.

Note that positive error associated to $\bar{X}_{(0)}$ (1) decreases as $i$ moves from 1 towards some point $p$ and that negative error associated to $\bar{X}_{(i)}(\mathbf{1})$ decreases as $i$ moves from $n$ towards the point $p$. Thus, $\bar{X}_{\langle p\rangle}(1)$ is the true value of $\mu$. If the true value of $\mu$ cannot be determined clearly at this stage, one can exclude the two extreme observations, namely the $1^{\text {st }}$ and the last ones and proceed with the same technique.

Now, excluding the two extreme observations namely $X_{(1)}$ and $X_{(n)}$ and retaining the remaining $(n-2)$ observations namely

$$
X_{(2)}<X_{(3)}<\ldots \ldots \ldots \ldots<X_{(n \square 1)}
$$

and then constructing the $(n-2)$ averages

$$
\bar{X}_{(0)}(2)=\frac{1}{n-3} \sum_{j=2, j \neq i}^{n-1} X_{0}, \quad(i=2,3, \ldots \ldots \ldots, n-1)
$$

such that $\quad \bar{X}_{(2)}(2)>\bar{X}_{(3)}(2)>\ldots \ldots \ldots . \bar{X}_{(n-2)}(2)>\bar{X}_{(n-1)}(2)$

it is obtained that $\mu$ lies within $X_{(s+1)}(2) \& X_{(s)}(2)$ with

$$
\bar{X}_{(s+1)}(2)<\mu<\bar{X}_{(s)}(2)
$$


Of course, it is trivial that

$$
\bar{X}_{(n-1)}(2)<\mu<\bar{X}_{(2)}(2)
$$

The inequality (2.14) can help, in the similar manner as in the earlier case, to determine the true value of $\mu$. At this stage, if the true value of $\mu$ cannot be determined clearly, one can exclude the four extreme observations namely $X_{(1)}, X_{(2)}, X_{(n-1)}$ and $X_{(n)}$ and proceed with the same technique.

Excluding the four extreme observations namely $X_{(1)}, X_{(2)}, X_{(n-1)}$ and $X_{(n)}$ and retaining the remaining $(n-4)$ observations namely

$$
X_{(3)}<X_{(3)}<\ldots \ldots \ldots . .<X_{(n \square 2)}
$$

and then constructing the $(n-4)$ averages

$$
\bar{X}_{(0)}(3)=\frac{1}{n-5} \sum_{j=3, j \neq i}^{n-2} X_{00}, \quad(i=3,4, \ldots \ldots \ldots, n-2)
$$

such that $\quad \bar{X}_{(3)}(3)>\bar{X}_{(4)}(3)>\ldots \ldots \ldots \ldots+\bar{X}_{(n-3)}(3)>\bar{X}_{(n-2)}(3)$

it is obtained that $\mu$ lies within $X_{(p+1)}(3) \& X_{(p)}$ (3) with

$$
\bar{X}_{(p+1)}(3)<\mu<\bar{X}_{(p)}(3)
$$

However in this case, it is trivial that

$$
\bar{X}_{(n-2)}(3)<\mu<\bar{X}_{(3)}(3)
$$

This inequality can help, in the similar manner, to determine the true value of $\mu$.

If the true value of $\mu$ cannot be determined clearly at this stage also, one can exclude the six extreme observations namely $X_{(1)}, X_{(2)}, X_{(3)}, X_{(n-2)}, X_{(n-1)}$ and $X_{(n)}$ and proceed with the same technique. The process can be continued further if necessary.

\section{Analysis of Annual Extremes of Ambient Air Temperature}

Temperature at a location attains at a maximum and at a minimum during the calendar year. Let $T_{1}, T_{2}, \ldots \ldots \ldots \ldots, T_{n}$ be the observed values of the maximum temperature occurred at a location during the calendar years $1,2,3, \ldots \ldots \ldots, n$ respectively. The fluctuation of the value of $\mathrm{T}$ occurs primarily because of the changing geo-environmental condition of the place which is natural as well as the chance error associated with its measurement. If we consider that the geo-environmental condition remains same except the seasonal variation, the annual maximum or the annual minimum temperature also remain the same during the study period and the variation would be because of the chance error only. Thus, if $\beta$ is the natural (corrected) annual maximum of temperature (NAMaxT) at the location,

$$
T_{i}=\beta+\varepsilon_{i} \quad, \quad(i=1,2, \ldots \ldots \ldots, n)
$$

where $\varepsilon_{i}$ is the chance error associated to the observation $T_{i}$.

Similarly if 
$t_{1}, t_{2}, \ldots \ldots \ldots \ldots, t_{n}$

be the observed values of the minimum temperature occurred at a location during the calendar years $1,2,3, \ldots \ldots \ldots . ., n$ respectively and $\alpha$ is the natural annual minimum of temperature (NAMinT) at the location,

$$
t_{i}=\alpha+e_{i} \quad, \quad(i=1,2, \ldots \ldots \ldots, n)
$$

where $e_{i}$ is the chance error associated to the observation $t_{i}$.

Thus, the method discussed above can be suitably applied to determine the values of the two parameters $\alpha$ and $\beta$.

\subsection{Determination of the NAMaxT at Guwahati:}

Observed values of annual maximum Temperature at Guwahati observed during the period from 1969 to 2010 have been collected from the meteorological department of India [6 \& 7]. These have been presented in Table - 3.1.1 and arranged in ascending order of magnitude in Table - 3.1.2. Computations of the value of the NAMaxT based on (i) all observations, (ii) all observations excluding the two extreme observations namely the $1^{\text {st }} \&$ the $23^{\text {rd }}$ ones, (iii) all observations excluding the four extreme observations namely the $1^{\text {st }}, 2^{\text {nd }}, 22^{\text {nd }} \& 23^{\text {rd }}$ ones and (iv) all observations excluding the six extreme observations namely the $1^{\text {st }}, 2^{\text {nd }}, 3^{\text {rd }}, 21^{\text {st }}, 22^{\text {nd }} \& 23^{\text {rd }}$ ones have been presented in Table $\mathbf{- 3 . 1 . 3}$, Table - 3.1.4, Table - 3.1.5 and Table - 3.1.6 respectively.

\section{Table - 3.1.1}

Observed values of Annual Maximum Temperature at Guwahati (in Degree Celsius)

\begin{tabular}{|c|c|c|c|c|c|c|c|}
\hline Year & $\begin{array}{c}\text { Observed } \\
\text { value }\end{array}$ & Year & $\begin{array}{c}\text { Observed } \\
\text { value }\end{array}$ & Year & $\begin{array}{c}\text { Observed } \\
\text { value }\end{array}$ & Year & value \\
\hline 1969 & 37.1 & 1979 & 38.6 & 1989 & 36.7 & 2002 & 35.7 \\
\hline 1970 & 36.6 & 1980 & 35.1 & 1990 & 36.0 & 2003 & 37.4 \\
\hline 1971 & 36.0 & 1981 & 35.8 & 1991 & 37.4 & 2004 & 38.0 \\
\hline 1972 & 35.7 & 1982 & 36.5 & 1992 & 39.4 & 2005 & 36.6 \\
\hline 1973 & 39.0 & 1983 & 36.7 & 1993 & 36.4 & 2006 & 38.0 \\
\hline 1974 & 36.1 & 1984 & 37.2 & 1994 & 37.3 & 2007 & 37.3 \\
\hline 1975 & 39.2 & 1985 & 36.5 & 1995 & 36.3 & 2008 & 37.3 \\
\hline 1976 & 39.0 & 1986 & 38.4 & 1996 & 37.2 & 2009 & 38.0 \\
\hline 1977 & 35.3 & 1987 & 37.2 & 2000 & 37.5 & 2010 & 37.2 \\
\hline 1978 & 36.8 & 1988 & 36.3 & 2001 & 36.7 & & \\
\hline
\end{tabular}




\section{Table - 3.1.2}

Observed values of Annual Maximum Temperature at Guwahati in ascending order (in Degree Celsius)

\begin{tabular}{|c|c|c|c|c|c|c|c|}
\hline $\begin{array}{c}\text { Serial } \\
\text { No }\end{array}$ & $\begin{array}{c}\text { Observed } \\
\text { value }\end{array}$ & $\begin{array}{c}\text { Serial } \\
\text { No }\end{array}$ & $\begin{array}{c}\text { Observed } \\
\text { value }\end{array}$ & $\begin{array}{c}\text { Serial } \\
\text { No }\end{array}$ & $\begin{array}{c}\text { Observed } \\
\text { value }\end{array}$ & $\begin{array}{c}\text { Serial } \\
\text { No }\end{array}$ & $\begin{array}{c}\text { Observed } \\
\text { value }\end{array}$ \\
\hline 1 & 35.1 & 7 & 36.3 & 13 & 37.1 & 19 & 38.4 \\
\hline 2 & 35.3 & 8 & 36.4 & 14 & 37.2 & 20 & 38.6 \\
\hline 3 & 35.7 & 9 & 36.5 & 15 & 37.3 & 21 & 39.0 \\
\hline 4 & 35.8 & 10 & 36.6 & 16 & 37.4 & 22 & 39.2 \\
\hline 5 & 36.0 & 11 & 36.7 & 17 & 37.5 & 23 & 39.4 \\
\hline 6 & 36.1 & 12 & 36.8 & 18 & 38.0 & & \\
\hline
\end{tabular}

\subsubsection{Computation of the Value of NAMaxT:}

Value of the NAMaxT at Guwahati has been determined from all the distinct observations and also from all the distinct observations excluding some extreme observations as shown below:

\section{Value of NAMaxT based on all distinct observed values:}

For determining the value of NAMaxT, one requires to construct the following table:

Table - 3.1.3

Mean of all observed values excluding the corresponding one (in Degree Celsius)

\begin{tabular}{|c|c|c|c|c|c|c|c|c|}
\hline $\begin{array}{c}\text { Serial } \\
\text { No }\end{array}$ & $\begin{array}{c}\text { Observed } \\
\text { value }\end{array}$ & Mean & $\begin{array}{c}\text { Serial } \\
\text { No }\end{array}$ & $\begin{array}{c}\text { Observed } \\
\text { value }\end{array}$ & Mean & $\begin{array}{c}\text { Serial } \\
\text { No }\end{array}$ & $\begin{array}{c}\text { Observed } \\
\text { value }\end{array}$ & Mean \\
\hline 1 & 35.1 & 37.1500 & 9 & 36.5 & 37.0864 & 17 & 37.5 & 37.0409 \\
\hline 2 & 35.3 & 37.1409 & 10 & 36.6 & 37.0818 & 18 & 38.0 & 37.0182 \\
\hline 3 & 35.7 & 37.1227 & 11 & 36.7 & 37.0772 & 19 & 38.4 & $\mathbf{3 7 . 0} *$ \\
\hline 4 & 35.8 & 37.1182 & 12 & 36.8 & 37.0727 & 20 & 38.6 & 36.9909 \\
\hline 5 & 36.0 & 37.1091 & 13 & 37.1 & 37.0591 & 21 & 39.0 & 36.9727 \\
\hline 6 & 36.1 & 37.1045 & 14 & 37.2 & 37.0545 & 22 & 39.2 & 36.9636 \\
\hline 7 & 36.3 & 37.0955 & 15 & 37.3 & 37.0500 & 23 & 39.4 & 36.9545 \\
\hline 8 & 36.4 & 37.0909 & 16 & 37.4 & 37.0455 & & & \\
\hline
\end{tabular}


It is observed that negative error associated to estimate is decreasing from the last estimate ' 36.9545 ' upwards and the positive error from the $1^{\text {st }}$ estimate ' 37.15 ' downwards approaching point ' 37.0 ' where error is zero. This means, the value of NAMaxT at Guwahati is 37.0 Degree Celsius.

Also by the inequality (2.10),

36.9 Degree Celsius < NAMaxT at Guwahati < 37.1 Degree Celsius

which means, NAMaxT at Guwahati $=37.0$ Degree Celsius.

\section{Value of NAMaxT based on all distinct observed values excluding the two} extreme observations namely the $1^{\text {st }} \&$ the $23^{\text {rd }}$ ones:

Let us construct the following table:

\section{Table - 3.1.4}

Mean of all observed values excluding the corresponding one (in Degree Celsius)

\begin{tabular}{|c|c|c|c|c|c|c|c|c|}
\hline $\begin{array}{c}\text { Serial } \\
\text { No }\end{array}$ & $\begin{array}{c}\text { Observed } \\
\text { value }\end{array}$ & Mean & $\begin{array}{c}\text { Serial } \\
\text { No }\end{array}$ & $\begin{array}{c}\text { Observed } \\
\text { value }\end{array}$ & Mean & $\begin{array}{c}\text { Serial } \\
\text { No }\end{array}$ & $\begin{array}{c}\text { Observed } \\
\text { value }\end{array}$ & Mean \\
\hline 1 & & & 9 & 36.5 & 37.0700 & 17 & 37.5 & 37.0200 \\
\hline 2 & 35.3 & 37.1300 & 10 & 36.6 & 37.0650 & 18 & 38.0 & 36.9950 \\
\hline 3 & 35.7 & 37.1100 & 11 & 36.7 & 37.0600 & 19 & 38.4 & 36.9750 \\
\hline 4 & 35.8 & 37.1050 & 12 & 36.8 & 37.0550 & 20 & 38.6 & 36.9650 \\
\hline 5 & 36.0 & 37.0950 & 13 & 37.1 & 37.0400 & 21 & 39.0 & 36.9450 \\
\hline 6 & 36.1 & 37.0900 & 14 & 37.2 & 37.0350 & 22 & 39.2 & 36.9350 \\
\hline 7 & 36.3 & 37.0800 & 15 & 37.3 & 37.0300 & 23 & & \\
\hline 8 & 36.4 & 37.0750 & 16 & 37.4 & 37.0250 & & & \\
\hline
\end{tabular}

In this case, it is observed that negative error associated to estimate is decreasing from the last estimate ' 36.935 ' upwards and the positive error from the $1^{\text {st }}$ estimate ' 37.13 ' downwards approaching point ' 37.0 ' where error is zero.

This means, the value of NAMaxT at Guwahati is 37.0 Degree Celsius.

Also by the inequality (2.15),

36.935 Degree Celsius < NAMaxT at Guwahati < 37.13 Degree Celsius

which means, NAMaxT at Guwahati $=37.0$ Degree Celsius 
3. Value of NAMaxT based on all distinct observed values excluding the four extreme observations namely the $1^{\text {st }}, 2^{\text {nd }}, 22^{\text {nd }} \&$ the $23^{\text {rd }}$ ones:

Let us construct the following table:

Table - 3.1.5

Mean of all observed values excluding the corresponding one (in Degree Celsius)

\begin{tabular}{|c|c|c|c|c|c|c|c|c|}
\hline $\begin{array}{c}\text { Serial } \\
\text { No }\end{array}$ & $\begin{array}{c}\text { Observed } \\
\text { value }\end{array}$ & Mean & $\begin{array}{c}\text { Serial } \\
\text { No }\end{array}$ & $\begin{array}{c}\text { Observed } \\
\text { value }\end{array}$ & Mean & $\begin{array}{c}\text { Serial } \\
\text { No }\end{array}$ & $\begin{array}{c}\text { Observed } \\
\text { value }\end{array}$ & Mean \\
\hline 1 & & & 9 & 36.5 & 37.05 & 17 & 37.5 & 36.9944 \\
\hline 2 & & & 10 & 36.6 & 37.0444 & 18 & 38.0 & 36.9666 \\
\hline 3 & 35.7 & 37.0944 & 11 & 36.7 & 37.03888 & 19 & 38.4 & 36.9444 \\
\hline 4 & 35.8 & 37.0888 & 12 & 36.8 & 37.0333 & 20 & 38.6 & 36.9333 \\
\hline 5 & 36.0 & 37.0777 & 13 & 37.1 & 37.0166 & 21 & 39.0 & 36.9111 \\
\hline 6 & 36.1 & 37.0722 & 14 & 37.2 & 37.0111 & 22 & & \\
\hline 7 & 36.3 & 37.0611 & 15 & 37.3 & 37.0055 & 23 & & \\
\hline 8 & 36.4 & 37.0555 & 16 & 37.4 & 37.0 & & & \\
\hline
\end{tabular}

In this case, it is observed that negative error associated to estimate is decreasing from the last estimate '36.9111' upwards and the positive error from the $1^{\text {st }}$ estimate ' 37.0944 ' downwards approaching point ' 37.0 ' where error is zero.

This means, the value of NAMaxT at Guwahati is 37.0 Degree Celsius.

Also by the inequality (2.20),

36.911 Degree Celsius < NAMaxT at Guwahati < 37.09 Degree Celsius

which means, NAMaxT at Guwahati $=37.0$ Degree Celsius

3. Value of NAMaxT based on all distinct observed values excluding the six extreme observations namely the first three $\&$ the last three:

Let us construct the following table: 
Table - 3.1.6

Mean of all observed values excluding the corresponding one (in Degree Celsius)

\begin{tabular}{|c|c|c|c|c|c|c|c|c|}
\hline $\begin{array}{c}\text { Serial } \\
\text { No }\end{array}$ & $\begin{array}{c}\text { Observed } \\
\text { value }\end{array}$ & Mean & $\begin{array}{c}\text { Serial } \\
\text { No }\end{array}$ & $\begin{array}{c}\text { Observed } \\
\text { value }\end{array}$ & Mean & $\begin{array}{c}\text { Serial } \\
\text { No }\end{array}$ & $\begin{array}{c}\text { Observed } \\
\text { value }\end{array}$ & Mean \\
\hline 1 & & & 9 & 36.5 & 37.01250 & 17 & 37.5 & 36.95000 \\
\hline 2 & & & 10 & 36.6 & 37.00625 & 18 & 38.0 & 36.91875 \\
\hline 3 & & & 11 & 36.7 & $\mathbf{3 7 . 0} *$ & 19 & 38.4 & 36.89375 \\
\hline 4 & 35.8 & 37.05625 & 12 & 36.8 & 36.99375 & 20 & 38.6 & 36.88125 \\
\hline 5 & 36.0 & 37.04375 & 13 & 37.1 & 36.97500 & 21 & & \\
\hline 6 & 36.1 & 37.0375 & 14 & 37.2 & 36.96875 & 22 & & \\
\hline 7 & 36.3 & 37.02500 & 15 & 37.3 & 36.9625 & 23 & & \\
\hline 8 & 36.4 & 37.01875 & 16 & 37.4 & 36.95625 & & & \\
\hline
\end{tabular}

In this case, it is observed that negative error associated to estimate is decreasing from the last estimate ' 36.88125 ' upwards and the positive error from the $1^{\text {st }}$ estimate ' 37.05625 ' downwards approaching point ' 37.0 ' where error is zero.

This means, the value of NAMaxT at Guwahati is 37.0 Degree Celsius.

Also by the inequality (2.24),

36.88125 Degree Celsius < NAMaxT at Guwahati < 37.05625 Degree Celsius

Of course, this inequality does not imply that

NAMaxT at Guwahati $=37.0$ Degree Celsius

Note: The true value of the NAMaxT at Guwahati can thus be confirmed to be 37.0 Degree Celsius.

\section{3-2. Determination of the NAMinT at Guwahati}

Observed values of Annual Minimum Temperature at Guwahati observed during the period from 1969 to 2010 have been collected from the meteorological department of India [6] \& [7]. These have been presented in Table - IV and arranged in ascending order of magnitude in Table - V. Table - VI has been constructed for interval values of the Natural Annual Minimum Temperature (abbreviated as NAMinT) at Guwahati applying the inequalities (3.6), (3.9), (3.12) \& (3.15). 
Table - 3.2.1

Observed values of Annual Minimum Temperature at Guwahati (in Degree Celsius)

\begin{tabular}{|c|c|c|c|c|c|c|c|}
\hline Year & $\begin{array}{c}\text { Observed } \\
\text { value }\end{array}$ & Year & $\begin{array}{c}\text { Observed } \\
\text { value }\end{array}$ & Year & $\begin{array}{c}\text { Observed } \\
\text { value }\end{array}$ & Year & $\begin{array}{c}\text { Observed } \\
\text { value }\end{array}$ \\
\hline 1969 & 5.8 & 1979 & 6.2 & 1989 & 6.7 & 2002 & 8.6 \\
\hline 1970 & 7.2 & 1980 & 6.4 & 1990 & 8.7 & 2003 & 8.0 \\
\hline 1971 & 5.9 & 1981 & 7.5 & 1991 & 7.4 & 2004 & 6.7 \\
\hline 1972 & 8.0 & 1982 & 6.2 & 1992 & 5.9 & 2005 & 8.4 \\
\hline 1973 & 5.0 & 1983 & 4.9 & 1993 & 7.8 & 2006 & 9.6 \\
\hline 1974 & 6.3 & 1984 & 6.1 & 1994 & 8.8 & 2007 & 6.4 \\
\hline 1975 & 7.2 & 1985 & 7.8 & 1995 & 7.5 & 2008 & 9.7 \\
\hline 1976 & 6.6 & 1986 & 8.6 & 1996 & 9.4 & 2009 & 9.8 \\
\hline 1977 & 6.2 & 1987 & 7.7 & 2000 & 8.5 & 2010 & 8.6 \\
\hline 1978 & 7.3 & 1988 & 9.2 & 2001 & 8.9 & & \\
\hline
\end{tabular}

Table - 3.2.2

Observed values of Annual Minimum Temperature at Guwahati in ascending order (in Degree Celsius)

\begin{tabular}{|c|c|c|c|c|c|c|c|}
\hline $\begin{array}{c}\text { Serial } \\
\text { No }\end{array}$ & $\begin{array}{c}\text { Observed } \\
\text { value }\end{array}$ & $\begin{array}{c}\text { Serial } \\
\text { No }\end{array}$ & $\begin{array}{c}\text { Observed } \\
\text { value }\end{array}$ & $\begin{array}{c}\text { Serial } \\
\text { No }\end{array}$ & $\begin{array}{c}\text { Observed } \\
\text { value }\end{array}$ & $\begin{array}{c}\text { Serial } \\
\text { No }\end{array}$ & \begin{tabular}{c} 
Observed value \\
\hline 1
\end{tabular} \\
\hline 4.9 & 8 & 6.4 & 15 & 7.7 & 22 & 8.8 \\
\hline 2 & 5.0 & 9 & 6.6 & 16 & 7.8 & 23 & 8.9 \\
\hline 3 & 5.8 & 10 & 6.7 & 17 & 8.0 & 24 & 9.2 \\
\hline 4 & 5.9 & 11 & 7.2 & 18 & 8.4 & 25 & 9.4 \\
\hline 5 & 6.1 & 12 & 7.3 & 19 & 8.5 & 26 & 9.6 \\
\hline 6 & 6.2 & 13 & 7.4 & 20 & 8.6 & 27 & 9.7 \\
\hline 7 & 6.3 & 14 & 7.5 & 21 & 8.7 & 28 & 9.8 \\
\hline
\end{tabular}




\subsubsection{Computation of the Value of NAMinT:}

Value of the NAMinT at Guwahati has been determined from all the distinct observations and also from all the distinct observations excluding some extreme observations as shown below:

\section{Value of NAMinT based on all distinct observed values:}

For determining the value of NAMinT, one requires to construct the following table:

$$
\text { Table - 3.2.3 }
$$

Mean of all observed values excluding the corresponding one (in Degree Celsius)

\begin{tabular}{|c|c|c|c|c|c|c|c|c|}
\hline $\begin{array}{c}\text { Serial } \\
\text { No }\end{array}$ & $\begin{array}{c}\text { Observed } \\
\text { value }\end{array}$ & Mean & $\begin{array}{c}\text { Serial } \\
\text { No }\end{array}$ & $\begin{array}{c}\text { Observed } \\
\text { value }\end{array}$ & Mean & $\begin{array}{c}\text { Serial } \\
\text { No }\end{array}$ & $\begin{array}{c}\text { Observed } \\
\text { value }\end{array}$ & Mean \\
\hline 1 & 4.9 & 7.68518 & 11 & 7.2 & $\mathbf{7 . 6 0} *$ & 21 & 8.7 & 7.54444 \\
\hline 2 & 5.0 & 7.68148 & 12 & 7.3 & 7.59629 & 22 & 8.8 & 7.54074 \\
\hline 3 & 5.8 & 7.65185 & 13 & 7.4 & 7.59259 & 23 & 8.9 & 7.53703 \\
\hline 4 & 5.9 & 7.64814 & 14 & 7.5 & 7.58888 & 24 & 9.2 & 7.52592 \\
\hline 5 & 6.1 & 7.64074 & 15 & 7.7 & 7.58148 & 25 & 9.4 & 7.51851 \\
\hline 6 & 6.2 & 7.63703 & 16 & 7.8 & 7.57777 & 26 & 9.6 & 7.51111 \\
\hline 7 & 6.3 & 7.63333 & 17 & 8.0 & 7.57037 & 27 & 9.7 & 7,50740 \\
\hline 8 & 6.4 & 7.62962 & 18 & 8.4 & 7.55555 & 28 & 9.8 & 7.50370 \\
\hline 9 & 6.6 & 7.62222 & 19 & 8.5 & 7.55185 & 21 & 8.7 & 7.54444 \\
\hline 10 & 6.7 & 7.61851 & 20 & 8.6 & 7.54814 & 22 & 8.8 & 7.54074 \\
\hline
\end{tabular}

It is observed that negative error associated to estimate is decreasing from the last estimate ' 7.54074 ' upwards and the positive error from the $1^{\text {st }}$ estimate ' 7.68518 ' downwards approaching point ' 7.6 ' where error is zero.

This means, the value of the NAMinT at Guwahati is 7.6 Degree Celsius.

Also by the inequality (2.10),

$$
\text { 7.5037 Degree Celsius < NAMaxT at Guwahati < } 7.68518 \text { Degree Celsius }
$$

which means, NAMinT at Guwahati $=7.6$ Degree Celsius

\section{Value of NAMinT based on the distinct observed values excluding the two extreme} ones namely the $1^{\text {st }} \&$ the $28^{\text {th }}$ ones:

Let us construct the following table: 
Table - 3.2.4

Mean of all observed values excluding the corresponding one (in Degree Celsius)

\begin{tabular}{|c|c|c|c|c|c|c|c|c|}
\hline $\begin{array}{c}\text { Serial } \\
\text { No }\end{array}$ & $\begin{array}{c}\text { Observed } \\
\text { value }\end{array}$ & Mean & $\begin{array}{c}\text { Serial } \\
\text { No }\end{array}$ & $\begin{array}{c}\text { Observed } \\
\text { value }\end{array}$ & Mean & $\begin{array}{c}\text { Serial } \\
\text { No }\end{array}$ & $\begin{array}{c}\text { Observed } \\
\text { value }\end{array}$ & Mean \\
\hline 1 & & & 11 & 7.2 & 7.62000 & 21 & 8.7 & 7.56000 \\
\hline 2 & 5.0 & 7.70800 & 12 & 7.3 & 7.61600 & 22 & 8.8 & 7.55600 \\
\hline 3 & 5.8 & 7.67600 & 13 & 7.4 & 7.61200 & 23 & 8.9 & 7.55200 \\
\hline 4 & 5.9 & 7.67200 & 14 & 7.5 & 7.60800 & 24 & 9.2 & 7.54000 \\
\hline 5 & 6.1 & 7.66400 & 15 & 7.7 & $7.60 *$ & 25 & 9.4 & 7.53200 \\
\hline 6 & 6.2 & 7.66000 & 16 & 7.8 & 7.59600 & 26 & 9.6 & 7.52400 \\
\hline 7 & 6.3 & 7.65600 & 17 & 8.0 & 7.58800 & 27 & 9.7 & 7,52000 \\
\hline 8 & 6.4 & 7.65200 & 18 & 8.4 & 7.57200 & 28 & & \\
\hline 9 & 6.6 & 7.64400 & 19 & 8.5 & 7.56800 & & & \\
\hline 10 & 6.7 & 7.64000 & 20 & 8.6 & 7.56400 & & & \\
\hline
\end{tabular}

In this case, it is observed that negative error associated to estimate is decreasing from the last estimate ' 7.52 ' upwards and the positive error from the $1^{\text {st }}$ estimate ' 7.708 ' downwards approaching point '7.6' where error is zero.

This means, the value of the NAMinT at Guwahati is 7.6 Degree Celsius.

Also by the inequality (2.15),

7.52 Degree Celsius < NAMaxT at Guwahati < 7.70 Degree Celsius

which means, NAMinT at Guwahati $=7.6$ Degree Celsius.

\section{Value of NAMinT based on the distinct observed values excluding the four}

Extreme observations namely the $1^{\text {st }}, 2^{\text {nd }}, 27^{\text {th }} \&$ the $28^{\text {th }}$ ones:

Let us construct the following table: 
Table - 3.2.5

Mean of all observed values excluding the corresponding one (in Degree Celsius)

\begin{tabular}{|c|c|c|c|c|c|c|c|c|}
\hline $\begin{array}{c}\text { Serial } \\
\text { No }\end{array}$ & $\begin{array}{c}\text { Observed } \\
\text { value }\end{array}$ & Mean & $\begin{array}{c}\text { Serial } \\
\text { No }\end{array}$ & $\begin{array}{c}\text { Observed } \\
\text { value }\end{array}$ & Mean & $\begin{array}{c}\text { Serial } \\
\text { No }\end{array}$ & $\begin{array}{c}\text { Observed } \\
\text { value }\end{array}$ & Mean \\
\hline 1 & & & 11 & 7.2 & 7.64347 & 21 & 8.7 & 7.57826 \\
\hline 2 & & & 12 & 7.3 & 7.63913 & 22 & 8.8 & 7.57391 \\
\hline 3 & 5.8 & 7.70434 & 13 & 7.4 & 7.63478 & 23 & 8.9 & 7.56956 \\
\hline 4 & 5.9 & 7.70000 & 14 & 7.5 & 7.63043 & 24 & 9.2 & 7.55652 \\
\hline 5 & 6.1 & 7.69130 & 15 & 7.7 & 7.62173 & 25 & 9.4 & 7.54782 \\
\hline 6 & 6.2 & 7.68695 & 16 & 7.8 & 7.61739 & 26 & 9.6 & 7.53913 \\
\hline 7 & 6.3 & 7.68260 & 17 & 8.0 & 7.60869 & 27 & & \\
\hline 8 & 6.4 & 7.67826 & 18 & 8.4 & 7.59130 & 28 & & \\
\hline 9 & 6.6 & 7.66956 & 19 & 8.5 & 7.58695 & & & \\
\hline 10 & 6.7 & 7.66521 & 20 & 8.6 & 7.58260 & & & \\
\hline
\end{tabular}

In this case, it is observed that negative error associated to estimate is decreasing from the last estimate '7.53913' upwards and the positive error from the $1^{\text {st }}$ estimate '7.70434' downwards approaching point '7.6' where error is zero.

This means, the value of the NAMinT at Guwahati is 7.6 Degree Celsius.

Also by the inequality (2.20),

7.53913 Degree Celsius < NAMinT at Guwahati < 7.70434 Degree Celsius which means, NAMinT at Guwahati = 7.6 Degree Celsius.

4. Value of NAMinT based on the distinct observed values excluding the six extreme observations namely the first three $\&$ the last three:

Let us construct the following table: 
Table - 3.2.6

Mean of all observed values excluding the corresponding one (in Degree Celsius)

\begin{tabular}{|c|c|c|c|c|c|c|c|c|}
\hline $\begin{array}{c}\text { Serial } \\
\text { No }\end{array}$ & $\begin{array}{c}\text { Observed } \\
\text { value }\end{array}$ & Mean & $\begin{array}{c}\text { Serial } \\
\text { No }\end{array}$ & $\begin{array}{c}\text { Observed } \\
\text { value }\end{array}$ & Mean & $\begin{array}{c}\text { Serial } \\
\text { No }\end{array}$ & $\begin{array}{c}\text { Observed } \\
\text { value }\end{array}$ & Mean \\
\hline 1 & & & 11 & 7.2 & 7.63809 & 21 & 8.7 & 7.56667 \\
\hline 2 & & & 12 & 7.3 & 7.63333 & 22 & 8.8 & 7.56190 \\
\hline 3 & & & 13 & 7.4 & 7.62857 & 23 & 8.9 & 7.55714 \\
\hline 4 & 5.9 & 7.70000 & 14 & 7.5 & 7.62380 & 24 & 9.2 & 7.54285 \\
\hline 5 & 6.1 & 7.69047 & 15 & 7.7 & 7.61428 & 25 & 9.4 & 7.53333 \\
\hline 6 & 6.2 & 7.68571 & 16 & 7.8 & 7.60952 & 26 & & \\
\hline 7 & 6.3 & 7.68095 & 17 & 8.0 & $7.60 *$ & 27 & & \\
\hline 8 & 6.4 & 7.67619 & 18 & 8.4 & 7.58095 & 28 & & \\
\hline 9 & 6.6 & 7.66667 & 19 & 8.5 & 7.57619 & & & \\
\hline 10 & 6.7 & 7.66190 & 20 & 8.6 & 7.57142 & & & \\
\hline
\end{tabular}

In this case, it is observed that negative error associated to estimate is decreasing from the last estimate '7.5333' upwards and the positive error from the $1^{\text {st }}$ estimate '7.70' downwards approaching point '7.6' where error is zero.

This means, the value of the NAMinT at Guwahati is 7.6 Degree Celsius.

Also by the inequality (2.24),

\subsection{Degree Celsius < NAMinT at Guwahati < 7.70 Degree Celsius}

which means, NAMinT at Guwahati $=7.6$ Degree Celsius

Note: The true value of the NAMinT at Guwahati can thus be confirmed to be 7.6 Degree Celsius.

\section{DISCUSSION}

1. The method developed here can be summarized as follows:

(i) Arrange the distinct observed values in ascending or descending order of

magnitude.

(ii) Corresponding to each observed value; compute the mean of the distinct observed all the distinct values excluding the former.

(iii) Observe the movements of the means from the highest as well as from the

lowest ones and determine the value of the parameter 
(iv) The value of the parameter can also be determined from the interval formed by the highest mean and the lowest mean.

(v) Confirm the correctness, of the result obtained, by repeating the process based on the observed values excluding

the extreme two observed values,

the extreme four observed values,

the extreme six observed values,

etc. respectively as required .

2. The existing statistical methods of estimation yield estimates which are not free from error. However, the method developed here yield the estimate which is free from error (i.e. exactly equal to the true value of the parameter).

3. It may be possible to apply this method in the determination of the true values of the parameters associated to the polynomial curves and to some other types of curves. However, it is yet to be investigated.

4. The estimated value computed by the existing methods of estimation varies if some observations are excluded and / or if some new observations are included. However, the value computed by the method developed here remains the same under this situation. Following findings (in Table 4.1, Table - 4.2, Table - 4.3 \& Table - 4.4) are some examples:

\section{Table - 4.1}

Maximum Likelihood / Minimum Variance Unbiased / Least Squares / Method of Moments / Minimum Chi Square Estimate of the NAMaxT at Guwahati if only one observation is excluded (in Degree Celsius)

\begin{tabular}{|c|c|c|c|c|c|c|c|c|}
\hline $\begin{array}{c}\text { Serial } \\
\text { No }\end{array}$ & $\begin{array}{c}\text { Excluded } \\
\text { observation }\end{array}$ & $\begin{array}{c}\text { Estimated } \\
\text { value }\end{array}$ & $\begin{array}{c}\text { Serial } \\
\text { No }\end{array}$ & $\begin{array}{c}\text { Excluded } \\
\text { observation }\end{array}$ & $\begin{array}{c}\text { Estimated } \\
\text { value }\end{array}$ & $\begin{array}{c}\text { Serial } \\
\text { No }\end{array}$ & $\begin{array}{c}\text { Excluded } \\
\text { observation }\end{array}$ & $\begin{array}{c}\text { Estimated } \\
\text { value }\end{array}$ \\
\hline 1 & 37.1 & 37.0591 & 9 & 36.8 & 37.0727 & 17 & 36.3 & 37.0955 \\
\hline 2 & 36.6 & 37.0818 & 10 & 38.6 & 36.9909 & 18 & 37.4 & 37.0455 \\
\hline 3 & 36.0 & 37.1000 & 11 & 35.1 & 37.1500 & 19 & 39.4 & 36.9545 \\
\hline 4 & 35.7 & 37.1200 & 12 & 35.8 & 37.1100 & 20 & 36.4 & 37.0909 \\
\hline 5 & 39.0 & 36.9727 & 13 & 36.5 & 37.0864 & 21 & 37.5 & 37.0409 \\
\hline 6 & 36.1 & 37.1045 & 14 & 36.7 & 37.0772 & 22 & 37.3 & 37.0500 \\
\hline 7 & 39.2 & 36.9636 & 15 & 37.2 & 37.0545 & 23 & 38.0 & 37.0182 \\
\hline 8 & 35.3 & 37.1400 & 16 & 38.4 & 37.0000 & & & \\
\hline
\end{tabular}


However, in each of these situations, the value of the NAMaxT at Guwahati by the method developed here has been found to be 37.0 Degree Celsius.

\section{Table -4.2}

Maximum Likelihood / Minimum Variance Unbiased / Least Squares / Method of Moments / Minimum Chi Square Estimate of the NAMinT at Guwahati if only one observation is excluded (in Degree Celsius)

\begin{tabular}{|c|c|c|c|c|c|c|c|c|}
\hline $\begin{array}{c}\text { Serial } \\
\text { No }\end{array}$ & $\begin{array}{c}\text { Excluded } \\
\text { observation }\end{array}$ & $\begin{array}{c}\text { Estimated } \\
\text { value }\end{array}$ & $\begin{array}{c}\text { Serial } \\
\text { No }\end{array}$ & $\begin{array}{c}\text { Excluded } \\
\text { observation }\end{array}$ & $\begin{array}{c}\text { Estimated } \\
\text { value }\end{array}$ & $\begin{array}{c}\text { Serial } \\
\text { No }\end{array}$ & $\begin{array}{c}\text { Excluded } \\
\text { observation }\end{array}$ & $\begin{array}{c}\text { Estimated } \\
\text { value }\end{array}$ \\
\hline 1 & 5.8 & 7.65185 & 11 & 7.5 & 7.58888 & 21 & 8.8 & 7.54074 \\
\hline 2 & 7.2 & 7.60000 & 12 & 4.9 & 7.68518 & 22 & 9.4 & 7.51851 \\
\hline 3 & 5.9 & 7.64814 & 13 & 6.1 & 7.64074 & 23 & 8.5 & 7.55185 \\
\hline 4 & 8.0 & 7.57037 & 14 & 7.8 & 7.57777 & 24 & 8.9 & 7.53703 \\
\hline 5 & 5.0 & 7.68148 & 15 & 8.6 & 7.54814 & 25 & 8.4 & 7.55555 \\
\hline 6 & 6.3 & 7.63333 & 16 & 7.7 & 7.58148 & 26 & 9.6 & 7.51111 \\
\hline 7 & 6.6 & 7.62222 & 17 & 9.2 & 7.52592 & 27 & 9.7 & 7,50740 \\
\hline 8 & 6.2 & 7.63703 & 18 & 6.7 & 7.61851 & 28 & 9.8 & 7.50370 \\
\hline 9 & 7.3 & 7.59629 & 19 & 8.7 & 7.54444 & & & \\
\hline 10 & 6.4 & 7.62962 & 20 & 7.4 & 7.59259 & & & \\
\hline
\end{tabular}

However, in each of these situations, the value of the NAMinT at Guwahati by the method developed here has been found to be 7.6 Degree Celsius.

\section{Table -4.3}

Maximum Likelihood / Minimum Variance Unbiased / Least Squares / Method of Moments / Minimum Chi Square Estimate of the NAMaxT at Guwahati if extreme observations are (in Degree Celsius)

\begin{tabular}{|c|l|c|c|c|c|}
\hline $\begin{array}{c}\text { Serial } \\
\text { No }\end{array}$ & \multicolumn{1}{|c|}{$\begin{array}{c}\text { Excluded } \\
\text { observation }\end{array}$} & $\begin{array}{c}\text { Estimated } \\
\text { value (in } \\
\text { Degree } \\
\text { Celsius) }\end{array}$ & Serial & Excluded observation & $\begin{array}{c}\text { Estimated } \\
\text { value (in } \\
\text { Degree } \\
\text { Celsius) }\end{array}$ \\
\hline 1 & None & 37.06086 & 6 & $1^{\text {st }}, 27^{\text {th }} \& 28^{\text {th }}$ & 36.93500 \\
\hline 2 & $1^{\text {st }}$ & 37.15000 & 7 & $1^{\text {st }}, 2^{\text {nd }}, 27^{\text {th }} \& 28^{\text {th }}$ & 37.02105 \\
\hline 3 & $28^{\text {th }}$ & 36.95450 & 8 & $1^{\text {st }}, 2^{\text {nd }}, 3^{\text {rd }}, 27^{\text {th }} \& 28^{\text {th }}$ & 37.09440 \\
\hline 4 & $1^{\text {st }} \& 28^{\text {th }}$ & 37.04280 & 9 & $1^{\text {st }}, 2^{\text {nd }}, 26^{\text {th }}, 27^{\text {th }} \& 28^{\text {th }}$ & 36.91110 \\
\hline 5 & $1^{\text {st }}, 2^{\text {nd }} \& 28^{\text {th }}$ & 37.13000 & 10 & $1^{\text {st }}, 2^{\text {nd }}, 3^{\text {rd }}, 26^{\text {th }}, 27^{\text {th }} \& 28^{\text {th }}$ & 36.98230 \\
\hline
\end{tabular}


However, in each of these situations, the value of the NAMaxT at Guwahati by the method developed here has been found to be 37.0 Degree Celsius.

\section{Table -4.4}

Maximum Likelihood / Minimum Variance Unbiased / Least Squares / Method of Moments / Minimum Chi Square Estimate of the NAMinT at Guwahati if extreme observations are (in Degree Celsius)

\begin{tabular}{|c|l|c|c|l|c|}
\hline $\begin{array}{c}\text { Serial } \\
\text { No }\end{array}$ & $\begin{array}{c}\text { Excluded } \\
\text { observation }\end{array}$ & $\begin{array}{c}\text { Estimated } \\
\text { value }\end{array}$ & $\begin{array}{c}\text { Serial } \\
\text { No }\end{array}$ & Excluded observation & $\begin{array}{c}\text { Estimated } \\
\text { value }\end{array}$ \\
\hline 1 & None & 7.58571 & 6 & $1^{\text {st }}, 27^{\text {th }} \& 28^{\text {th }}$ & 7.52000 \\
\hline 2 & $1^{\text {st }}$ & 7.68518 & 7 & $1^{\text {st }}, 2^{\text {nd }}, 27^{\text {th }} \& 28^{\text {th }}$ & 7.62500 \\
\hline 3 & $28^{\text {th }}$ & 7.50370 & 8 & $1^{\text {st }}, 2^{\text {nd }}, 3^{\text {rd }}, 27^{\text {th }} \& 28^{\text {th }}$ & 7.70434 \\
\hline 4 & $1^{\text {st }} \& 28^{\text {th }}$ & 7.60384 & 9 & $1^{\text {st }}, 2^{\text {nd }}, 26^{\text {th }}, 27^{\text {th }} \& 28^{\text {th }}$ & 7.53913 \\
\hline 5 & $1^{\text {st }}, 2^{\text {nd }} \& 28^{\text {th }}$ & 7.70800 & 10 & $1^{\text {st }}, 2^{\text {nd }}, 3^{\text {rd }}, 26^{\text {th }}, 27^{\text {th }} \& 28^{\text {th }}$ & 7.61816 \\
\hline
\end{tabular}

However, in each of these situations, the value of the NAMinT at Guwahati by the method developed here has been found to be 7.6 Degree Celsius.

\section{References}

Allan B., On the Foundations of Statistical Inference" Journal of the American Statistical Association, vol. 57 , pp. $269-306,1962$.

Barnard G. A., Statistical Inference, Journal of the Royal Statistical Society, Series B, vol. 11, pp. $115-149,1949$.

Brye W., The Normal Distribution: Characterizations with Applications, published by Springer Verlag, ISBN 0 - 387 - $97990-5.1995$.

Bernoulli J., Arts Conjectandi, published by Impensis Thurmisiorum Fratrum Basileae. 1713.

Chakrabarty D., Probability: Link between the Classical Definition and the Empirical Definition, $J$. Ass. Sc. Soc., 45, 13-18, June 2005.

Chakrabarty D., Bernoulli's Definition of Probability: Special Case of Its Chakrabarty's Definition, Int. J. Agricult. Stat. Sci., 4(1), 23 - 27, 2008.

De Moivre A., De Mensura Sortis, published by Philosophical Transaction of the Royal Society,1711. 
De Moivre A., The Doctrine of Chances, 1st Edition (2nd Edition in 1738 \& 3rd Edition in 1756), ISBN $0-8218-2103-2.1718$.

Hald A., On the History of Maximum Likelihood in Relation to Inverse Probability and Least Squares, Statistical Science, vol. 14, pp. 214 - 222, 1999.

Hazewinkel M., Normal Distribution, Encyclopedia of Mathematics, Springer, ISBN 978 - 1 - 55608 $-010-4,2001$.

Ivory, On the Method of Least Squares, Phil. Mag., vol. LXV, pp. 3 - 10, 1825.

John A., Fisher's Inverse Probability of 1930, International Statistical Review, vol. 68, pp. 155 - 172, 2000.

Kendall M. G. and Stuart A., Advanced Theory of Statistics, Vol. 1 \& 2, $4^{\text {th }}$ Edition, New York, Hafner Press, 1977.

Le Cam L., Maximum likelihood — an introduction, ISI Review, vol. 58, no. 2, pp. 153 -171, 1990.

Lehmann E. L. \& Casella G, “ Theory of Point Estimation”, 2nd ed. Springer. ISBN 0 - 387 - 98502 $-6,1998$.

Marsagilia G., Evaluating the Normal Distribution, Journal of Statistical Software, 11 (4), 2004.

Stigler S. M., A Modest Proposal : A New Standard for the Normal, The American Statistician, 36 (2), $137-138,1982$.

Walker H. M., De Moivre on the Law of Normal Probability, In Smith, David Eugene. A Source Book in Mathematics, Dover, ISBN 0 - 486 - 64690 - 4, 1985.

Walker H. M. \& Lev J., Statistical Inference, Oxford \& IBH Publishing Company. 1965. 